\title{
Interactive Whiteboards in Brazilian's Primary School: New Barriers
}

\author{
http://dx.doi.org/10.3991/ijet.v10i6.4804 \\ Rodolfo Fernandes Esteves, Silvio Henrique Fiscarelli, José Luís Bizelli \\ Univ. de Estadual Paulista, Araraquara, Brazil.
}

\begin{abstract}
This article focuses on presenting the results from the research Barreiras para implementação da Lousa Digital Interativa: um estudo de caso, thus contributing to the systematization of knowledge about the implementation of this didactic-pedagogic resource. Starting from the set of barriers listed in the BECTA report of the 2004, we have elaborated a panorama composed of the barriers, their main characteristics and whether they occur in the context of the Brazilian school being studied. The field study consisted of an analysis of available hardware and software, interviews with the principal and teachers, as well as direct observation in the classrooms. As a result, we will present an analysis of the barriers in the aforementioned report which were found in the Brazilian context. Furthermore, two new barriers emerge in Brazilian public schools.
\end{abstract}

Index Terms: Interactive Whiteboard, ICT, Barriers, Implementation.

\section{INTRODUCTION}

Information and communications technologies (ICT) have been one of the big innovation possibilities in the teaching-learning process for little more than a decade [1]. Some examples of their uses are presented in the BECTA's report [2], which presents the implementation of new technologies - such as portable computers, interactive boards and the Internet - in a combination of software, hardware and connectivity, resulting in significant improvement in the teaching and learning process. Gains according to the E-learning Nordic report [3] are not limited to students' performance, but also to their commitment and motivation to learn. Additionally, other works [4] [5] also state that one possibility for improving teaching quality is to innovate, renew methodologies and vary the ways information is presented to students. Such innovations are often associated to the use of technology in the teaching process.

Aiming to invest in policies for the improvement of education quality, dozens of municipal school departments in Brazil have been acquiring the so-called Interactive Whiteboards, a tool which has been gaining ground, in the media and specialized literature, as a technological resource capable of helping teachers transmit information to their students in a more efficient and appropriate way. However, if we observe recent history, we will see how complex it is to introduce innovations in school organizations [6] [7] [8], that is, these changes' consolidation in the educational process is not easily implemented, since it doesn't depend only on teachers' will and support from the school management team. If we analyze schools as complex organizations comprised of physical, material, human and financial resources, we can identify barriers to technologies incorporation and consequently to innovation.

"Ref. [9]" defines barrier as "any condition that makes it difficult to make progress or to achieve an objective". The "Ref [10]" presents a wide range of barriers to technology use in the classroom. The report points to the existence of restrictive elements - internal or external to the school which hamper technology incorporation to pedagogical practice. Therefore, if we wish to comprehend the technology implementation process, it is fundamental to investigate these barriers, as well as the effective teaching conditions, among other limiting factors which occur in the teaching and learning process - a process to which all schools are subjected at large.

Thus, we reiterate, starting from the growing implementation of Interactive Whiteboards (IWB) in Brazilian public schools and the lack of studies on the barriers that compromise their use in the classroom, this work aims to analyze to which degree the barriers described in the "Ref [10]" are present in the Brazilian school context and whether it is possible to identify other barriers other than the ones listed in the report. Even though this is a study about a municipal school in Araraquara, São Paulo, we researched and systematized knowledge about the subject in Brazil as a whole, broadening the debate regarding the adoption of public policies for the improvement of national education quality.

\section{INTERACTIVE WhiteboARds As A TEACHING AND LEARNING RESOURCE}

Interactive Whiteboards consist of a set of technological equipment organized so as to fulfill a specific task. Such equipment comprise: a motor user interaction system, a projector to project information from the computer, the computer itself (which manages all interactions) and the software, which offers diverse tools, enabling its users to prepare activities, presentations and actions, in conjunction with the computer's other applications. Many configuration options regarding the hardware which comprises an Interactive Whiteboard exist, but the traditional and most common configuration consists of a multimedia projector, a computer and a board. In general terms, we can say that IWBs are like a big computer screen; they are, however, smarter, because they operate with a simple touch, either of a finger, a pen or specific tool.

With IWBs, teachers can afford a much more natural attitude in the classroom in comparison to when only simple projections are used, because in this last case, the teacher has to stay near the computer and the mouse and, as a result, interaction with the students is diminished and content presentation is hampered. 
"Ref [11]" present a brief summary of Interactive Whiteboard's main applications: "Presenting software or web resources to the whole class; Moving and manipulating objects in real time [12]; Increasing interaction capacity between student and content; Being used as simulators, allowing to manipulate variables, make predictions and see phenomena which would be otherwise impossible to observe [13]. Showing animations or videos to help explain concepts; Making the learning process more contextual- ized; Presenting students' works to the rest of the group; Creation of digital flipcharts; Text manipulation and handwriting practice; Saving notes and activities done by the students on the whiteboard for future analysis".

Other authors present more positive effects: IWB benefits on teaching and learning, classified in general benefits, benefits for students and benefits for teachers are listed on table 1 (extracted from [14]):

TABLE I.

ACTIVITIES DEVELOPED ON THE INTERACTIVE WHITEBOARD.

\begin{tabular}{|c|c|c|}
\hline General benefits & Benefits for teachers & Benefits for students \\
\hline $\begin{array}{l}\text {-Versatility, with applications for all } \\
\text { ages across the curriculum [15]; } \\
\text { - Increases teaching time by allowing } \\
\text { teachers to present web-based and other } \\
\text { resources more efficiently [16]; } \\
\text { - More opportunities for interaction and } \\
\text { discussion in the classroom, especially } \\
\text { compared to other ICT [17]; } \\
\text { - Increases enjoyment of lessons for } \\
\text { both students and teachers through } \\
\text { more varied and dynamic use of } \\
\text { resources, with associated gains in } \\
\text { motivation [18]; }\end{array}$ & $\begin{array}{l}\bullet \text { Enables teachers to integrate ICT into their } \\
\text { lessons while teaching from the front of the class } \\
\text { [19]; } \\
\text { - Encourages spontaneity and flexibility, } \\
\text { allowing teachers to draw on and annotate a wide } \\
\text { range of web-based resources [20]; } \\
\text { - Enables teachers to save and print what is on } \\
\text { the board, including any notes made during the } \\
\text { lesson, reducing duplication of effort and } \\
\text { facilitating revision [21]; } \\
\text { - Allows teachers to share and re-use materials, } \\
\text { reducing workloads [22]; } \\
\text { - Widely reported to be easy to use, particularly } \\
\text { compared with using a computer in whole-class } \\
\text { teaching [19]; } \\
\text { - Inspires teachers to change their pedagogy and } \\
\text { use more ICT, encouraging professional } \\
\text { development [15]; }\end{array}$ & $\begin{array}{l}\bullet \text { Increases enjoyment and motivation; }[23][24] \text {; } \\
\text { - Greater opportunities for participation and } \\
\text { collaboration, developing students' personal and social } \\
\text { skills; [18]; } \\
\text { - Reduces the need for note-taking through the } \\
\text { capacity to save and print what appears on the board; } \\
{[18] \text {; }} \\
\text { - Students are able to cope with more complex } \\
\text { concepts as a result of clearer, more efficient and more } \\
\text { dynamic presentation [19]; } \\
\text { - Different learning styles can be accommodated as } \\
\text { teachers can call on a variety of resources to suit } \\
\text { particular needs [13]; } \\
\text { - Enables students to be more creative in presentations } \\
\text { to their classmates, increasing self-confidence [18]; } \\
\text { - Students do not have to use a keyboard to engage } \\
\text { with the technology, increasing access for younger } \\
\text { children and students with disabilities [25]; } \\
\text { - Improves performance [12] [23] [24] [26]; }\end{array}$ \\
\hline
\end{tabular}

\section{BARRIERS TO THE IWB IMPLEMENTATION}

In the BECTA agency's report, we can conclude that two types of barriers exist - internal and external - but they are, to a certain degree, related. Teachers' lack of confidence and anxiety regarding the computer, resistance to and negative attitudes towards changes and nonperception of benefits are considered internal barriers; while lack of access to the resources, lack of time, lack of teachers' competence and technical problems are external barriers.

Still regarding the two types of barrier, [27] point to the existence of complex inter-relations between the levels and the barriers between them, classifying them as show in Table II (extracted from [10]).

TABLE II.

EXTERNAL AND INTERNAL BARRIERS

\begin{tabular}{|c|c|}
\hline EXTERNAL BARRIERS & INTERNAL BARRIERS \\
\hline $\begin{array}{l}\text { - Lack of access to resources. } \\
\text { - Lack of time. } \\
\text { Lack of teachers' } \\
\text { competence. } \\
\text { Technical problems. }\end{array}$ & $\begin{array}{l}\text { - Teachers' lack of confidence } \\
\text { and anxiety regarding the } \\
\text { computer. } \\
\text { - Resistance to change and } \\
\text { negative attitudes. } \\
\text { - Non-perception of benefits. }\end{array}$ \\
\hline
\end{tabular}

To the set of barriers mentioned, we can add the need of effective changes both in work methodology and in classroom didactics, because teachers need to know when and how to use the tool, that is, what sort of information will be presented better to students with the IWB, or which contents are understood better with the tool. Otherwise, the IWB will not be used in all its potential, being turned into a mere multimedia projector, used only to project contents, ignoring its main virtue: interactivity.

Finally, the BECTA report- quoting [28] - claims that the school's organization, with its rules and rigid schedules, as well as its isolating attitude, does not support experience exchange and dissemination of practices regarding ICTs. Even if external barriers do not exist or are overcome, there are still other barriers to be considered, such as the educational system itself, which often limits innovative strategies regarding ICTs, due to its rigid and uncompromising structure.

\section{CASE Study OF A School Unit}

Araraquara, a city in São Paulo state, has 40 ERC (education and recreation centers), 14 municipal elementary schools; 28 state elementary schools; 15 state high schools; 17 private elementary schools and 18 private high schools. Approximately 8700 children attend the municipal nursery school network, through 35 children's education units and two preschool groups in rural areas, and 7272 students attend elementary school.

For this research, we conducted a detailed study in a municipal school considered a case of good practices with the IWB, that is, a model to be followed and reached by other units. According to School Census/INEP 2011 data, the unit is attended by 489 students from early years (1st to 5 th grade), divided in two shifts (morning and afternoon), and is served by 30 teachers. The school holds the best educational indicators in the city, and for having achieved the best IDEB indicators for consecutive years, it has deservedly obtained two extra sets of interactive whiteboards. 
We defined, with the school administration, three dates of technical visits, destined to analyzing the IWB set hardware and software - and its operation. Subsequently, we conducted semi-structured interviews with the school unit's principal and three teachers who work with the IWB. The purpose of the interviews was to understand the implementation process from two different perspectives: the school administrator's and that of those who use the tool, the teachers. Next, in loco observations were carried out in three groups' classes (3rd grade A, 3rd grade B and 5 th grade $\mathrm{C}$ ), aiming to verify the teachers' individual practices in using the IWBs.

\section{RESUlts AND Discussion}

Based on the set of barriers listed on the [10], we elaborated a table comprised of the barrier itself, its main characteristics and its occurrence in the context of the school studied. Data and information used in the elaboration of the table III were obtained by the analysis of hardware available at the school, interviews with administrator and teachers and direct class observation in three groups. The setting regarding barriers found in the school is summarized as follows.

TABLE III.

SUMMARY OF BARRIERS AND OCCURRENCE

\begin{tabular}{|c|c|c|}
\hline BARRIER & CHARACTERISTICS & OCCURRENCE \\
\hline $\begin{array}{l}\text { Teachers' lack of } \\
\text { confidence and anxie- } \\
\text { ty regarding the } \\
\text { computer. }\end{array}$ & $\begin{array}{l}\text { Fear of students noticing that the teachers do not } \\
\text { know how to use the equipment. Teachers' fear in } \\
\text { face of technology derives from the fear of losing } \\
\text { their professional status, from how they see the } \\
\text { increasing use of computers in teaching as a possi- } \\
\text { bility of removal or disqualification of their tradi- } \\
\text { tional pedagogical competences. }\end{array}$ & $\begin{array}{l}\text { There were no reports of "lack of confidence and anxiety" from the } \\
\text { teachers regarding ICT use in classroom. }\end{array}$ \\
\hline $\begin{array}{l}\text { Lack of teachers' } \\
\text { competence }\end{array}$ & $\begin{array}{l}\text { If training is insufficient or inappropriate, teachers } \\
\text { will not be prepared enough and will not have } \\
\text { enough confidence to use technology fully in and } \\
\text { out of the classroom. The barrier can be divided in: } \\
\text { lack of time for training, lack of skills training and } \\
\text { lack of focus on ICT during teachers' initial train- } \\
\text { ing. }\end{array}$ & $\begin{array}{l}\text { In regard to competence, teachers claim to have undertaken, even if } \\
\text { long ago, some computer course and received basic training for using } \\
\text { the IW. }\end{array}$ \\
\hline $\begin{array}{l}\text { Lack of access to } \\
\text { resources }\end{array}$ & $\begin{array}{l}\text { Lack of hardware and software can seriously limit } \\
\text { what teachers can do in the classroom concerning } \\
\text { ICTs. Such barrier can be divided in: lack of } \\
\text { hardware, bad organization of resources, bad } \\
\text { quality hardware, inappropriate software and lack } \\
\text { of personal access to the teacher. }\end{array}$ & $\begin{array}{l}\text { The lack of resources affects software quality - both the A-Migo } \\
\text { software, as well as applications provided by repositories. As far as } \\
\text { low quality hardware is concerned, only the interactive pen falls short } \\
\text { of expectations in the unit's IW set. No occurrence of any of the other } \\
\text { sub-barriers related to lack of resources was reported or verified during } \\
\text { in loco research. Examples of sub barriers would be: bad organization } \\
\text { of resources and lack of personal access to the teacher. }\end{array}$ \\
\hline Lack of time & $\begin{array}{l}\text { Lack of available time to complete the assigned } \\
\text { tasks; among them, mastering ICTs is certainly } \\
\text { affected by this hindrance. }\end{array}$ & $\begin{array}{l}\text { Lack of time for training can be considered a barrier in the school. } \\
\text { Training sessions proved to be unfeasible to the teachers, due to the } \\
\text { schedules offered by the Municipal Education Board (SME - Secretar- } \\
\text { ia Municipal de Educação, in Portuguese). By and large, however, the } \\
\text { lack of training barrier does not occur, once two teachers reported } \\
\text { having taken computer courses offered by the SME. }\end{array}$ \\
\hline Technical problems & $\begin{array}{l}\text { Problems that may occur during the class and spoil } \\
\text { the plans of ICT use and which, fundamentally, } \\
\text { can result in an increase of teachers' fears towards } \\
\text { technology. This barrier can be divided in: Fear of } \\
\text { things going wrong and Lack of technical support. }\end{array}$ & $\begin{array}{l}\text { Regarding technical problems and its sub barriers (fear of things going } \\
\text { wrong and lack of technical support), no account of this barrier's } \\
\text { current occurrence was verified. During the interviews, teachers } \\
\text { claimed that, at first, they feared some of the defects could not be } \\
\text { solved without technical support. However, as it was reported, such } \\
\text { misgivings do not exist anymore, once teachers learned how to handle } \\
\text { defects by themselves and knew that, when necessary, the technical } \\
\text { support would solve the problems quickly. }\end{array}$ \\
\hline $\begin{array}{l}\text { Resistance to change } \\
\text { and negative attitudes }\end{array}$ & $\begin{array}{l}\text { "Ref [29]" explains that teachers are often wary of } \\
\text { implementing new ideas without proof of their } \\
\text { efficiency, and tend to adopt a new technology } \\
\text { only when it helps them do what they are doing in } \\
\text { a better way. Teachers defend points of view that } \\
\text { persist during the implementation of innovations } \\
\text { and, as a result, educational change becomes a } \\
\text { slow process. }\end{array}$ & $\begin{array}{l}\text { During the research, no resistance or negative attitudes from the school } \\
\text { or the teachers regarding the IW use was verified. }\end{array}$ \\
\hline $\begin{array}{l}\text { Non-perception of } \\
\text { benefits }\end{array}$ & $\begin{array}{l}\text { Teachers have no understanding of how ICTs will } \\
\text { benefit their work and students' learning. }\end{array}$ & $\begin{array}{l}\text { During the research, it was verified that both school and teachers } \\
\text { involved had already overcome this barrier. }\end{array}$ \\
\hline $\begin{array}{l}\text { Official state exams } \\
\text { impact }\end{array}$ & $\begin{array}{l}\text { Some evidence suggests teachers avoid using ICT } \\
\text { during periods in which their students are studying } \\
\text { for official state exams. }\end{array}$ & No occurrence of this barrier was found. \\
\hline Difference in age & $\begin{array}{l}\text { A small number of teachers suggested that teach- } \\
\text { ers' age was a factor which raised barriers to the } \\
\text { ICT use, older teachers being less prone to engage } \\
\text { with technology due to their advanced age. }\end{array}$ & The technology use/age barrier was not significant in the case studied. \\
\hline Difference in gender & $\begin{array}{l}\text { A small amount of evidence pointing to the corre- } \\
\text { lation between teachers' sex and ICTs use level } \\
\text { was found. Correlation between sex and anxiety } \\
\text { levels regarding the computer was also reported, } \\
\text { anxiety levels being higher in women than in men. }\end{array}$ & $\begin{array}{l}\text { No occurrence of such barrier was verified, once the teaching staff } \\
\text { consists only of female teachers. }\end{array}$ \\
\hline
\end{tabular}


According to the data presented, we can notice that some of the barriers were not verified in a significant way or, in other cases, are only partially present. However, as pointed in the analysis, there are still many obstacles to be overcome. Many actions need to be taken so that the IWB can be used adequately and efficiently in the classroom.

A more detailed analysis of the school's context reveals at least two barriers which were not included in the set listed in the [10]. These are new barriers identified by this research which may help to understand better the IWB implementation process in Brazilian public schools. The first barrier consists of obstacles arising from the lack of physical and spatial suitability to the ICTs incorporation in the classroom, the second barrier concerns teachers' lack of ability to relate digital contents to the curriculum.

Physical and logistical resources are of great importance to the implementation process of any kind of improvement and/or technology in school units, once they often hinder or prevent use due to structural or architectural limitations. Among the spatial organization problems for proper IWB use, we highlight a few that we consider most important, such as the fact that there are only two sources of energy (electrical outlets) in the classroom, one below the blackboard and another in the back of the classroom. There are no switches to turn off the classroom lights and the projector requires low light for better viewing, leading the teacher to go to the electric distribution board, outside the classroom, to turn off the lights every time they use the IWB and to turn the lights on when they finish.

In the Figure 1, we present the set arrangement. Among the problems of the set disposition in the classroom, it is possible to notice that the wires connecting the IWB to the laptop, the laptop to the stabilizer and the stabilizer to the outlet are in the middle of the way to the classroom entrance and in front of the IWB. This disposition can lead to three basic problems: compromising wires and cables durability, obstructing accessibility and risk of electric shock for teachers and students.

Due to children's height, teachers keep their desks on the sides of the classroom instead of facing the group. Thus, the distance between the teacher's desk and the electricity outlet below the blackboard is bigger. The solution for this problem was to use a student's desk to bring the set elements closer to each other and to the outlet. We verified, however, that such solution is a mere palliative, because the wires are still loose when they should be protected inside appropriate chutes fixed to the walls, which would prevent the wires from wearing out due to handling and avoiding risks of electric shock for teachers and students.

As to the second identified barrier, teachers' lack of skill in relating digital contents to the curriculum, we verified that educators have great difficulty in autonomously finding contents in digital media to contextualize or plan their classes on the IWB: they are bereft of in-depth knowledge to notice how the use of digital resources can assist teaching strategies. Up to the moment we conducted the study, teachers showed no skill to select and organize relevant digital contents relevant to the curriculum. A big part of the teaching staff does not prepare the materials to be used in class in advance and does not create lesson plans for the activities with the IWB. Overall, teachers sporadically use contents from educational websites and/or
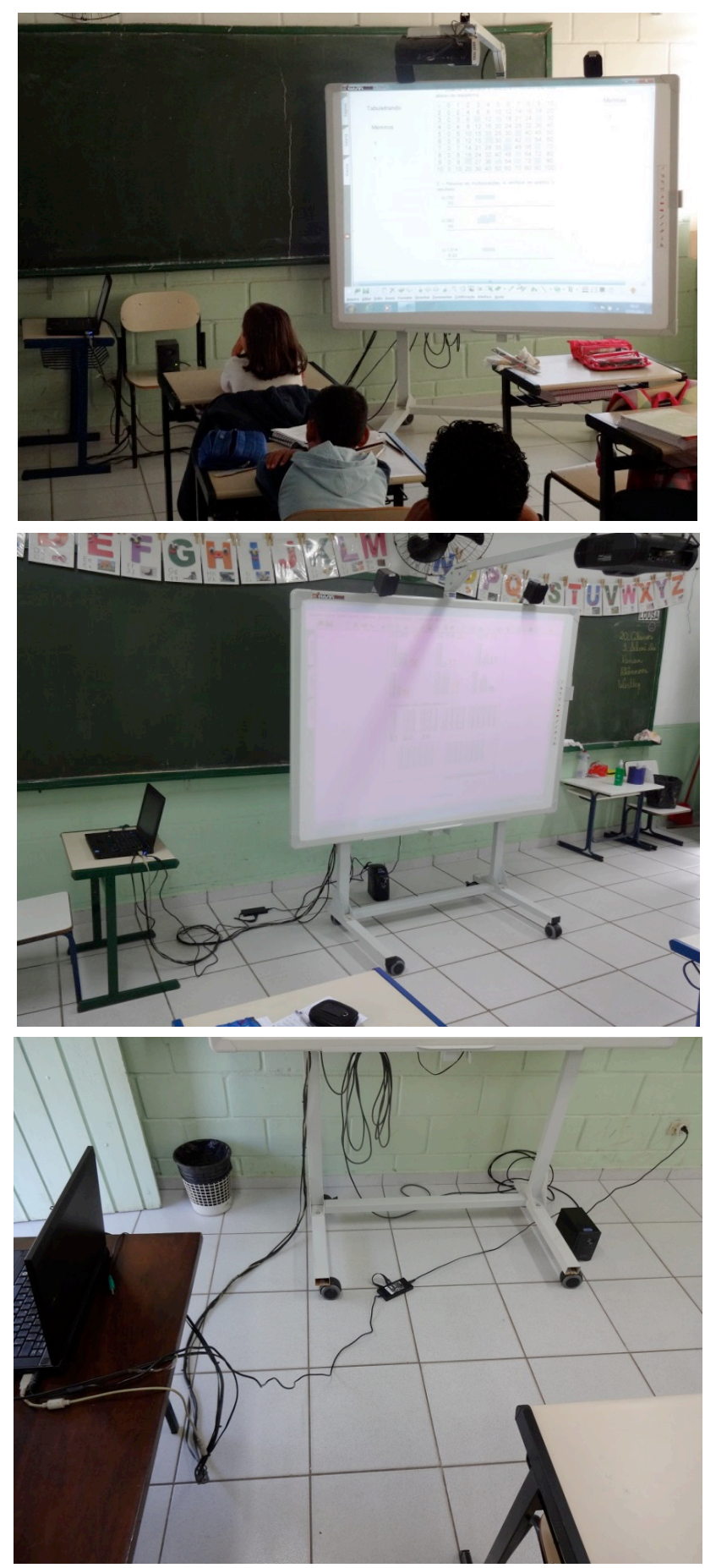

Figure 1. Set disposition.

educational games found in the course book and or/ materials prepared by third parties.

Thus, the ability to identify digital contents appropriate to various curriculum subjects is a fundamental task to fully explore IWB's potential. In this sense, the lack of teacher training, the absence of reflection over which digital content to use and the unawareness of the best way of exploring the resource during classes constitute a barrier for working with IWBs in order to streamline the pedagogic process and engage students in the process of constructing and elaborating knowledge. 


\section{FINAL CONSIDERATIONS}

The IWB has been used in a non-systematized way in schools since 2004. Market research shows a tendency of increase - only $4 \%$ of Brazilian classrooms adopted the technology in the last ten years - which, surprisingly, is concentrated in public schools.

A great part of the literature concerning IWBs' impact and potential evaluates the resource positively, based on teachers' and students' opinions about the tool's characteristics and use possibilities. Nevertheless, a great part of the difficulties happen in the IWB implementation process, in the teachers' appropriation of the technology and adjustment to the curriculum. This research's results show that there is a set of barriers for the use of IWB in schools. Many indispensable resources to their operation in public schools have yet to be provided, that is, there is a shortage of physical/spatial adequacy for the incorporation of ICTs in the classrooms, teachers lack skills to relate digital contents to the curriculum and there is a paucity of software that contemplate the school curriculum satisfactorily and allow to explore IWBs' maximum potential [30].

IWB use demands certain specific needs. In addition to acquiring the technology itself, teachers need to be trained to learn how to handle the devices and use all their resources appropriately. We can say that IWBs' usefulness is deeply related to the type and quality of materials it utilizes [31]. Software is an important element for IWBs' quality of use, as well as teachers' creativity when planning classes which explore technological resources, not turning innovations in a new means to traditional contents. The software must provide a new experience to the students, leading them to a more active and collective engagement during the class. This is one of the schools' main demands to interactive whiteboards suppliers.

\section{REFERENCES}

[1] Eurydice, Key Data on Learning and Innovation through ICT a School in Europe 2011, Education, Audiovisual and Culture Executive Agency P9 Eurydice, Brussels, 2001. (ICT@Europe.edu).

[2] B. Somekh, et al., Evaluation of the Primary Schools Whiteboard Expansion Project - summary report. London: Report to the Department for Children, Schools and Families. 2007. http://downloads01.smarttech.com/media/research/international_re search/uk/becta executive expansion summary.pdf

[3] S. G. Pedersen, et al., E-learning Nordic 2006- Impact of ICT in education, Ramboll Management, Copenhaga. 2006. http://www.oph.fi/download/47637 eLearning Nordic English.pd f

[4] A. Balanskat, R. Blamire, S. Kefala, S. The ICT impact report. A review of studies of ICT impact on schools in Europe. European Communities: European Schoolnet, 2006.

[5] Netp, National Education Technology Plan 2010. Government Report, USA. 2010.

[6] M. L. Belloni, Educação a Distância. Campinas, SP.: Autores Associados, 1999.

[7] P. Kirkbridge, Gerir a Mudança. In: STACEY, R. Pensamento Estratégico e Gestão da Mudança - Perspectivas internacionais sobre dinâmica organizacional. Lisboa: Publicações Dom Quixote. 1998.

[8] M. A. P. N. Almeida, Aprender a Gerir as Organizações no Século XXI. Lisboa: Áreas Editora. 2005

[9] K.W. Schoepp, Technology Integration Barriers in a TechnologyRich Environment. 2005. http://www.zu.ac.ae/lthe/vol2no1/lthe02 05.pdf

[10] Becta (2004) A Review of the Research Literature on Barriers to the uptake of ICT by Teachers. Retrieved from: http://dera.ioe.ac.uk/1603/1/becta_2004_barrierstouptake_litrev.pd f

[11] R.F. Esteves, S. H. Fiscarelli, C. B. G. Souza, As barreiras para implementação das TIC na sala de aula. Revista Ibero-Americana de Estudos em Educação, 9 (3), pp. 583-598. 2014 http://seer.fclar.unesp.br/iberoamericana/article/view/7619/5300

[12] D. A. Essig, Case Study of Interactive Whiteboard Professional Development for Elementary Mathematics Teachers, PhD, Walden University, 2011.

[13] M. A. Bell, Why use an interactive whiteboard? A baker's dozen reasons!. 2002.http://www.teachers.net/gazette/JAN02/mabell.htm

[14] R.F. Esteves, S. H. Fiscarelli, C. B. G. Souza, A lousa digital interativa como instrumento de melhoria da qualidade da educação - um panorama geral. Revista Eletrônica de Política e Gestão Educacional. n.15, pp.186-197. 2013. http://www.fclar.unesp.br/Home/ Departamentos/CienciasdaEducacao/RevistaEletronica/artigo-4--a-lousa-digital...-rodolfo-fernandes-esteves1.pdf

[15] A. Smith, Interactive whiteboard evaluation. MirandaNet. 1999. http://www.mirandanet.ac.uk/pubs/smartboards.htm

[16] D. Walker, Quality at the dockside. TES Online. pp. 66-67. 2003.

[17] F. Gerard, et al.; Using SMART Board in foreign language classrooms. Paper presented at SITE 99: Society for Information Technology and Teacher Education International Conference, San Antonio, Texas, 28 February-4 March 1999.

[18] P. Levy, Interactive Whiteboards in learning and teaching in two Sheffield schools: a developmental study. Sheffield: Department of Information Studies, University of Sheffield. 2002.

[19] H. Smith, SmartBoard evaluation: final report. Kent NGfL. 2001.http://www.kented.org.uk/ngfl/whiteboards/report.html

[20] S. Kennewell, Interactive whiteboards - yet another solution looking for a problem to solve? Information Technology in Teacher Education, 39, pp.3-6. 2001.

[21] D. Walker, White enlightening. Times Educational Supplement. p. 19. 2002.

[22] D. Glover, D. Miller, Running with technology: the pedagogic impact of the large-scale introduction of interactive whiteboards in one secondary school. Journal of Information Technology for Teacher Education, 10 (3), pp.257-276. 2001. http://dx.doi.org/10.1080/14759390100200115

[23] J. Syh-Jong, Integrating the interactive whiteboard and peer coaching to develop the TPACK of secondary science teachers. Computers \& Education, (55) 4. 2010.

[24] P. Digregorio, K. Sobel-Lojeski, The effects of interactive whiteboards (IWBS) on student performance and learning. A literature review. Journal of Educational Technology Systems, 38 (3), pp. 255-312. 2009. http://dx.doi.org/10.2190/ET.38.3.b

[25] T. A. M. Goodison, Learning with ICT at primary level: pupils' perceptions. Journal of Computer Assisted Learning 18, pp.282295. 2002. http://dx.doi.org/10.1046/j.0266-4909.2002.00240.x

[26] C. Campbell, P. Kent, Using interactive whiteboards in pre-service teacher education. Examples from two Australian universities, Australasian Journal of Educational Technology, 26 (4), pp. 447463. 2010.

[27] R. Snoeyink, Ertmer, P. Thrust into technology: how veteran teachers respond. Journal of Educational Technology Systems, 30 (1), pp.85-111. 2001. http://dx.doi.org/10.2190/YDL7-XH09RLJ6-MTP1

[28] L. Cuban, H. Kirkpatrick, C. Peck, High access and low use of technologies in high school classrooms: explaining an apparent paradox. American Educational Research Journal, 38 (4), pp. 813 834. 2001. http://dx.doi.org/10.3102/00028312038004813

[29] P. Albaugh, The role of skepticism in preparing teachers for the use of technology. 'Education for community': a town and gown discussion panel, Westerville, $\mathrm{OH}, 1997$.

[30] J. L. Bizelli, Inovação: limites e possibilidades para aprender na era do conhecimento. São Paulo: Cultura Acadêmica. 2013.

[31] V. Quashie, How interactive is the interactive whiteboard? Mathematics Teaching, 214, 33-38. 2009. http://thejournal.com/Articles/ 2010/08/04/Interactive-Whiteboards-Truths-and-Consequences. aspx?Page $=1$ 


\section{AUTHORS}

R.F. Esteves - Graduate in Social Sciences (Teacher Education degree from FACERES - 2007 and Bachelor from UNESP-FCLAr - 2013) and specialist in Politic Sociology from FACERES (2008). He has been a student and coordinator at the research group IAGE (acronym for Informatics Applied to Education Management, in Portuguese) since 2012. Esteves was also actively involved with the studies Learning Objects - A concrete approach of new technologies' use in the school and Learning Objects in the classroom: Resources, methodologies and strategies for improving learning quality, both coordinated by Silvio Henrique Fiscarelli, PhD. He has a master's degree in School Education from UNESP-FCLAr (2014) with the dissertation entitled Barriers to the implementation of Interactive Whiteboards - A case study. Esteves is currently a Graduate $\mathrm{PhD}$ student in School Education, also at UNESP-FCLAr.

S. H. Fiscarelli - Graduate in Social Sciences, MA and $\mathrm{PhD}$ in School Education from the College of Sciences and Letters of Araraquara (FCLAr), UNESP - Univ Estadual Paulista. His post doctorate research in New Technologies was conducted at the Engineering College of Guaratinguetá, UNESP. He is an Assistant Professor at the Didactics Department at the College of Sciences and Letters of Araraquara as well as research coordinator of the FAPESP Youth Investigators program. Fiscarelli has expe- rience in Education, especially in Education Management and New Technologies.

J. L. Bizelli - Graduate in Architecture from the Pontifical Catholic University of São Paulo (1980), MA (1990) and PhD (2003) in Sociology from UNESP, Univ Estadual Paulista. He is a Full Professor at College of Sciences and Letters of Araraquara, UNESP, lecturing in Public Policies Management. He is also accredited in the Digital Television: Information and Knowledge (FAAC-UNESP, Bauru) and School Education (FCLAr-UNESP, Araraquara) Graduate Programs. Bizelli coordinates a CNPq research group entitled Governance for Administration, focusing mainly on: innovation, sustainable development, governance in public institutions, ICTs for Distance Education and educational applications for Interactive Television. Having done his post doctorate at the Ciencias de la Educación department of the Universidad de Alcalá de Henares (UAH), in Spain, he was part of the staff responsible for the cooperation agreement on Education between UNESP and UAH. He was the dean of FCLAr, Araraquara, and president of its Publishing Laboratory between 2009 and 2012. Bizelli is the editor of the Revista IberoAmericana de Estudos em Educação and Unesp Publishing Foundation's communication advisor.

This work was supported in part by (grant 2012/06526-1 - São Paulo Research Foundation- FAPESP). Submitted 15 june 2015. Published as resubmitted by the authors 15 November 2015 . 